\title{
The Translation of the Sibylla TibURtina InTO MidDLE WELSH
}

NELY VAN SEVENTER

\section{Introduction}

The Sibylla Tiburtina is a medieval prophetic text with roots in Late Antiquity. It tells the story of the wise Sybil, who is summoned to the court of the Roman emperor when a hundred of his senators dream the same dream during the same night. Her explanation of this dream is a lengthy prophecy about future kings and their qualities and faults, as well as about the natural disasters and wars the future will bring. The whole culminates in a prophecy about the signs of the Day of Judgment.

The text has a long and complicated history of transmission. Originally written in Byzantine Greek, it has undergone considerable changes since being translated into Latin around the turn of the first millennium. Of this Latin text we have an edition with variants published by Ernst Sackur (1898). More recently, Anke Holdenried has worked extensively on the various versions of the Latin Sybil, and the differences between them, notably in her book The Sybil and her Scribes (Holdenried 2006). The first extant vernacular translation is in Norman French and dates from the twelfth century. There are two Middle Welsh versions of this text, one in Peniarth 14, the other in the Red Book of Hergest [RB] and the White Book of Rhydderch [WB]. In this paper, the latter will be discussed. There are only slight variations between these two versions, and I base my text on RB as edited recently on the Welsh Prose 13001425 project (Luft et al. 2013), with a few variant readings from WB in the same corpus. For the sake of clarity, I have silently amended capitalisation and punctuation.

The Latin source of this translation is unknown, but must, as Marged Haycock has noted (Haycock 2005: 123), have been close to Sackur's text. All translations are my own. In my research I am interested in the translation process of the text from Latin into Middle Welsh, and in this paper I discuss some of the general tendencies of the Welsh translator of Sibli Ddoet 'the wise Sybil'.

That the text was translated from Latin, rather than through the intermediary of, for example, Old French, seems to be implied by the presence of Latinisms in the Welsh version. Many of these constructions, however, are just as likely to be renderings of Old French as direct 
translations from Latin. For example, in the phrase qui ergo ex ea nascitur 'the one then, that will be born from her' (Sackur 1898: 179.26), the Welsh translation (RB 139v: 571, c. 9) is yr hwnn a aner o honno. This seems to be a straightforward Latinism, ${ }^{1}$ until the Old French is considered, and specifically an Old French version that is very close to the Latin text. ${ }^{2}$ This version renders qui ergo ex ea nascitur as cil qui naistera de $l i$ 'the one who will be born from her' (Baron and Haffen 1987: 89.89), which is not only a word-for-word translation of the Latin, but syntactically even closer to the Welsh than the Latin: cil qui matches $y r$ hwnn $a$ - the subject followed by relative particle or pronoun - while Latin grammar allows for a simple qui functioning both as subject and as relative pronoun.

Therefore, in order to establish that we are really dealing with a direct translation from Latin, we have to rule out the possibility of a Romance intermediary, and there is one translating glitch that may help us in this task. In the middle of the 'Kings' list' occupying the middle part of the text, Sybil says in Latin (lines 460, 463): Et fiet terre motus per loca diversa et insularum civitates (et regiones) demersione dimergentur (Sackur 1898: 184.5-6) 'and the earth shall tremble in various places and the cities and regions of the islands shall be flooded with floods'. ${ }^{3}$ The Old French version translates this phrase correctly as movemens de terre sera fais par divers lieus, et les cités des illes seront plongiés, par diversion (Baron and Haffen 1987: 93.231-3) 'the earth will move in different places, and the cities of the islands will be sunk by flooding'. The Welsh text, however, has ac y kryn y dayar yn amryuaelon leoed, ac ynyssoed a dinassoed a brenhinaethyeu a sodir o voduaeu (RB 140v: 574.10-12) 'and the earth shall tremble in various places, and islands and cities and kingdoms will be submerged by floods'. ${ }^{4}$ The Welsh translator however missed the genitive clause of insularum civitates 'the cities of the islands', and replaced this by islands and cities. It would be surprising to encounter such a mistake in a translation from French, as les cités des illes is not easily mistaken for les cités et les illes. Insularum civitates, on the other hand, might indeed cause problems, especially if we keep in mind

\footnotetext{
${ }^{1}$ Relatives with $y r$ hwnn are cited by various scholars to be a marker of translation, but, as Luft argues, they are also found in 'native' texts (Luft 2016: 176).

${ }^{2}$ MS 539, municipal library of Rennes, edition by Baron and Haffen 1987: 87-96.

${ }^{3}$ Although this translation may seem unfortunate, it reflects the Latin where demersione and dimergentur (sic) are both forms of the verb demergo 'to sink, to submerge'. I think the repetitiveness of the phrase is intended, as it mimics certain Hebraisms in the Bible, and thus gives the phrase something of an 'Old Testament' feel, fitting for a prophetess.

4 These brenhinaethyeu 'kingdoms' are a translation of regiones 'regions', an addition only found in the Latin manuscripts called D, G and B by Sackur, and may therefore hint towards the source of the Welsh text.
} 
that the ending -rum of the genitive was often abbreviated with a shorthand symbol. Our translator might have mistaken the symbol for another, representing et. Such a mistake is plausible when translating from Latin, for both the ending -rum and the word et had so many different abbreviations throughout the centuries and in different countries, that not recognizing one and guessing at another could happen. The same thing doesn't work at all if we consider the text to have been translated from French. Note, too, that the Welsh has kept the Latin word order by putting the 'islands' before the 'cities'.

While comparing the Welsh text with the Latin source text in Sackur's edition, taking into account the variants, certain particularities, or quirks, of the translator appeared and reappeared consistently. Thus we begin to get to know our translator.

\section{Grasping grammar}

The first thing we might say is that the translator's grasp of Latin grammar seems quite poor. In the translations of passages he did not understand properly, we see three things happening. On occasion, the translation is obviously faulty, where there was probably no awareness of the misunderstanding; in other cases, phrases are omitted, whether consciously or unconsciously; finally, phrases are sometimes altered, seemingly on purpose. The first phenomenon may be demonstrated in two important passages which have been changed due to faulty translation.

The first example forms part of the so-called "Sibylline Gospel", Sibyl's prophecy about the life of Jesus. She delivers this prophecy in front of the 'priests of the Hebrews' (effeireit gwyr Effrei), and the following is their answer:

Wynteu a dywedassant: "Na chredwn, kanys tystolyaeth a geir a rodes an tadeu ynn..."

(RB 139v: 571 c.24-26)

They then said: "we will not believe, because of the testament and word our fathers gave to us $[\ldots]$."

This is a translation of the following Latin passage:

At illi dixerunt: "Nos non credemus, quia verbum et testamentum dedit Deus patribus nostris [...]."

(Sackur 1898: 180.7-8)

And they said: "we for our part will not believe, because of the word and Covenant that God has given to our fathers [...]." 
$A$ rodes an tadeu ynn 'that our fathers gave to us' is a significant mistranslation. Instead of God giving a Covenant to their fathers, the Welsh version has their fathers giving a 'testimony' to the Hebrews, due to the translator having skipped over the essential word Deus 'God', and changed the case of patribus 'to our fathers'. The Welsh version is only possible if patribus is taken to be an acting nominative instead of a receiving dative (!). And of course, for the Welsh translation to work, nostris 'our' in the genitive would need to be a dative nobis 'to us'.

The second example comes from the last section of the Tiburtina, the prophecy about the Last Emperor:

A'r brenhin hwnnw a vyd a llythyr geyr y vronn yn wastat. Ac yn $y$ llythyr yn yscriuennedic brenhin, ar darestwng idaw pop teyrnas gristonogawl, holl dinassoed ac ynyssed y paganyeit a distriw, ac eu temloed a diwreireida, a'r holl paganyeit a dwc y gret. Ac yr holl temloed y werthuawr groc a dyrcheuir

(RB 140v 575.14-20)

And that king will constantly have a document in front of him. And in the document [it is] written [that the] king, in order to submit every Christian kingdom, will destroy all the cities and the islands of the Pagans. And he will demolish their temples and he will lead all the Pagans to the faith. And in all the temples the precious cross will be raised.

Ac yn y llythyr yn yscriuennedic brenhin, ar darestwng 'and in the letter, written, the king, in order to submit', is not idiomatic Welsh: it is in fact incomprehensible. The Latin has in this place Et ipse rex scripturam habebit ante oculos dicentem: "Rex Romanorum omne sibi vindicet regnum christianorum" (Sackur 1898: 185.8-10), 'And that king will have a writing in front of his eyes, saying: "The king of the Romans shall claim his reign over all the Christians"', which is followed by the account of the destruction of Pagan temples, etc. At first sight, yscriuennedic might seem to be a faulty translation of scripturam: this accusative singular of scriptura 'written text' might have been wrongly taken to be a participle, 'written'. But scriptura has already been correctly translated as llythyr. It seems, rather, to be translating dicentem: this literally means 'saying', but given that it refers to the scripturam, it would make sense to translate as 'written'. Therefore, the first part of the phrase, et ipse rex scripturam habebit ante oculos 'and this king will have a text before his eyes' has been translated correctly, if freely. The following part, dicentem: "Rex Romanorum...", 'saying [that] "the king of the Romans..." is problematic, but we must bear in mind that the medieval text does not have modern 
punctuation. The element dicentem Rex Romanorum is in the same sequence as Welsh yscriuennedic brenhin, where the translator has interpreted the text incorrectly. He has also added an explanatory ac yn $y$ llythyr 'and in the text', an attempt to make something understandable out of a phrase which he did not understand himself.

The translator's second tactic for dealing with parts of the text he did not understand, by simply skipping over them, is harder to prove in a short article like this, because every omission on its own could be explained by a skip of the eye, a lack in the source manuscript, or other reasons. However, when one goes through the whole text, it becomes clear that passages of a higher grammatical complexity are by far the ones omitted most often.

The third tactic, consisting of making up a phrase from parts he did understand, is more interesting as it yields some surprising results that may also help us enter into the mindset of our medieval translator.

The following passage is from the description of the dream of the hundred senators:

$Y$ nawuet heul oed ry dywyll yn y chylch ogylch, ac yn y pherued un paladyr yn goleuhav

(RB139r: 571 b.4-6).

The ninth sun was extremely dark in its entirety, with one spear glowing in its centre.

Yn y chylch ogylch 'in its entirety', is an addition in the Welsh text, as is yn y pherued 'in its centre'. The Latin has unum tantum habens radium fulgentem (Sackur 1898: 178.26) 'having only one fiery ray'. The verb habere is particularly difficult to translate into Welsh, a language with no verb 'to have' (Welsh expresses possession by means of prepositions, e.g. mae gan y dyn lyfr 'the man has a book', literally 'there is a book with the man'). In this case, the translator has apparently judged that an adverbial phrase localising the 'fiery ray' and thus avoiding habere altogether was his best choice.

\section{Writing (Welsh) literature}

But in some cases, the translation seems to diverge from the original for literary effect rather than as a result of linguistic difficulties. This may be illustrated by a description of one of the kings in the lengthy middle part of the text, where the Sibyl foretells the coming and going of whole lineages: 
A hwnnw gwr aflonyd vyd, kadarn yn ymlad, a llawer a gerda o vor a thir. Ac ny cheiff y elynyon le llaw (arnaw ${ }^{5}$ ). Ac ef a uegys yn dyn deholedic odieithyr y deyrnas, a'e eneit o'r diwed a a y teyrnas Nef ar Duw.

(RB 140r: 572.17-22)

And that one will be a restless man, strong in battle, and he will travel a lot on sea and on earth. And his enemies will not get hold of him. And like an exile, he will go out of his kingdom, and his soul will in the end go to heaven, and to God.

Where the Welsh has aflonydd 'restless', the Latin has nimis bellicosus (Sackur 1898: 182.9) 'extremely warlike'. The main meaning of aflonydd lies in the semantic field of 'restless, troubled' or even 'fearful'; 'merciless' is less common. ${ }^{6}$ There are other, closer ways to translate 'extremely warlike', but 'restless' goes very well with llawer a gerda 'he will travel a lot, will traverse much/many (places)'. This is not altogether precise as a translation: the Latin has et multum erit persecuturus (Sackur 1898:182 1. 10) 'he will be pursued, persecuted, a lot'. Although a man fleeing from his persecutors will undoubtedly travel a lot, the Welsh loses a layer of meaning. Ac ny cheiffy elynyon le llaw arnaw 'and his enemies will not get hold of him': the Welsh expression is idiomatic, and translates the Latin et non dabitur in manus inimicorum (Sackur 1898: 182), 'and he will not be given into the hand of enemies'. Our translator tries his hand at writing literature here, making real Welsh out of the Latin, and the way in which he "recycles" the word manus 'hand' in the Welsh idiom cael lle llaw 'to get hold', shows a certain wittiness only appreciated when one has access to both the Latin and Welsh texts.

The last part of this little passage is ac ef a uegys yn dyn deholedic odieithyr $y$ deyrnas a'e eneit o'r diwed a a y teyrnas Nef ar Duw. The Latin formula is quite different: et morietur exul extra regnum et anima eius in manu Dei (Sackur 1898: 182.11-12) 'and he will die in exile from his kingdom, and his soul will be in God's hand'. This is not a mistranslation. It is rather a free rendering, one that transfers the meaning, rather than the actual wording of the phrase. Most of the time, our translator tries to stay as close to the Latin texts as possible, but here in the first part of the passage he comes up with the expression lle llaw (one may imagine him being quite pleased with himself), and then he continues in the same free-flowing, but semantically correct vein.

\footnotetext{
${ }^{5}$ Arnaw features in the White Book, but not in the Red Book.

${ }^{6}$ http://geiriadur.ac.uk, s.v. aflonydd.
} 
There are many examples of a more literary style in this text, and many phrases bear witness to a genuine effort not only to translate the text, but to translate it into Welsh - that is to say, to inscribe it in the Welsh literary tradition. For example, in the introduction, where the Sibyl is introduced to the reader, we find our first nyt amgen, 'no other' used for 'that is to say, i.e.', which is a Welshism par excellence:

Sibli a damgylchyna6d amryuaelon vrenhinaetheu y d6yrein, nyt amgen: yr Asia, a gwlat Alexander ma6r, a Galilea, a Cicilia a Phampilia, a Galacia.

(RB 139r: 571a.6-9)

Sibyl travelled through the various kingdoms of the East, that is to say: Asia, the country of Alexander the Great, Galilee, Sicily, Pamphylia, and Galatia.

And after the senators have asked the Sybil to explain their dream to them, she begins, as an answer, her long monologue which makes up most of the rest of the text. This answer is introduced by a hitheu a dywawt 'and she said'.

Hitheu is the conjunctive form of $h i$ 'she'. It can be translated 'and she, for her part', which implies often that somebody else spoke first. Latin also has a form with this function. The construction used in the corresponding passage in the Latin text is illa dixit at eos 'and she said to them'. In Latin, it isn't necessary to write the personal pronoun, as the person is already reflected in the declination of the verb, so using illa also effects a certain emphasis on the person speaking. The Welsh form hitheu, though, is stronger in this contrastive emphasis, and is extensively used in native Welsh literature in exactly the same type of situation, where in a dialogue an author wants to clarify who the speakers are. ${ }^{7}$

\section{Pious additions}

Another quirk of the Welsh Tiburtina is the translator's habit of enhancing religious passages (those that pertain to the life of Jesus) with various flourishes. This practice can be exemplified by a long passage from the prediction of the Passion:

Ac wynt a rodant idaw bonclusteu o ysgymynyon dwylaw, ac yn y wyneb kyssegredic y poerant poer gwennwynyawl. Ac a dyry ef y geuyn gwerthuawr udunt o'e uadeu, ac yr kymryt amarch y gantunt. Ef a deu.

\footnotetext{
${ }^{7}$ On the function of conjunctive pronouns in Middle Welsh, see Mac Cana 1990, and more recently Parina 2007.
} 
Yn vwyt idaw y rodant bystyl, ac yn diawt idaw gwin egyr a wallonyant. Ac ar brenn diodeifeint a'e crogant, ac a'e lladant. Ac ny rymhaa udunt hynny o dim, kanys y trydyd dyd y kyuyt o veirw.

(RB 139v: 571c.38-571d.4)

And they will give him slaps with detestable hands, and in his holy face they will spit venomous spittle. And he will turn his precious back to them in forgiveness, and accept disgrace from them. He will be silent. And they will serve him gall for food and as a drink they will serve him vinegar, and the will crucify him on the tree of passion, and they will kill him. And that will not benefit them at all, for on the third day he will rise from the dead.

The Latin source text of this passage is a citation from Augustine's De Civitate Dei (Holdenried 2006: 61) which is common to all Latin versions. The first phrase is a literal translation, albeit a beautifully poetic one. The second, Ac a dyry ef.... Ef a deu, is harder to relate to its Latin source. The Latin has dabit vero ad verbera simpliciter dorsum sanctum et colaphos accipiens tacebit (Sackur 1898: 180.16-18), meaning 'but he will simply give his holy back to the whips and, receiving the fists, he will be silent'.

There are small differences in the first part of the phrase. Welsh has omitted simpliciter 'simply', and translated sanctum 'holy' as gwerthuawr 'precious'. After that, the two phrases - the Latin original and the Welsh translation - start to differ so much that we may speak of "interpretation" rather than of "translation". The reference to the whips is omitted in the Welsh which, instead, adds that Jesus turns his back motivated by forgiveness. In the Latin, he then receives fists in silence, whereas in the Welsh, he receives amarch 'disgrace' or 'insult' from them. This is a theological interpretation, stressing Jesus's virtues of forgiveness and lowliness in a way which is absent from the original version. The last part of the passage, ac ar brenn diodefeint a'e crogant 'and they will crucify him on the wood of passion' is another interpreting translation. The Latin simply states et suspendent eum in ligno (Sackur 1898: 180.19-20) 'and they will hang him on wood'. The translator shows his religious engagement with the event by adding 'passion' and 'to crucify' to the Sibyl's theologically more neutral account, a neutrality that might have been deliberate, given that her role is that of the "pagan prophetess", the one who foretells the miracles of Christ from an outsider's perspective. [K]yuyt o veirw 'he will rise from the dead' is another religious formula. The Latin has resurget (Sackur 1898: 180.20), which is the Latin ecclesiastical formula, but without a morte 'from the dead'. The translator seems, in this section of the prophecy which concerns one of the central narratives of Christianity, to be led more by his own experience and knowledge of the subject than by what his exemplar actually states. One 
can almost feel his enthusiasm for it, or at least one can imagine the way this passage touches him personally, through the free translation and the liberal use of insertions that strengthen the narrative in general or introduce certain emphases that are absent from the source text.

Most variations between the Latin and Welsh versions are of this order. We have the results of the translator's poor grasp of Latin: grammatical errors, omissions, and "creative translating", meaning that the translator made up phrases from parts of an otherwise ill-understood phrase, thus creating his own meaning. In addition to "creative writing" out of necessity, where the translator seems to guess what a given part should mean, there are also conscious changes. Many of them are there for aesthetic reasons, making the text fit better into the native literary standards, and others are motivated by piety, as we have seen in the passage about the Passion.

All these are very minor changes, when one compares this translation to those of other continental tales, such as Chwedleu Seith Doethon Rufein (The Tales of the Seven Sages of Rome), translated from the Old French Sept Sages de Rome, which lies on the other end of the spectrum, as it has been heavily condensed and has undergone considerable changes (van Seventer 2011), or the three romances from the Mabinogion. Sioned Davies has written of the links between the texts in that collection and the oral tradition of storytelling: she remarks that the three romances, although "loose retellings" of the courtly romances of Chrétien de Troyes, are "completely adapted to the native culture, and remain stylistically and structurally within the Welsh narrative tradition" (Davies 2007: xi).

Virtually no such adaptation can be seen here. A reason for this might be that we are dealing with a text which was perceived as religious by the translator, and as Ceridwen Lloyd-Morgan writes, staying close to the "essential meaning of the text [was] a particularly important consideration when religious, and especially liturgical, texts were translated" (Lloyd-Morgan 1978: 175). ${ }^{8}$

Whether or not the Tiburtina is a religious text or a political one is a matter of controversy: although the text is traditionally seen by scholars as being political in the first instance, placing emphasis on the prophecy about the kings, Anke Holdenried has challenged this view with her thesis that the text is primarily a religious prophecy about the Incarnation of Christ (Holdenried 2006, passim). Given the extreme faithfulness towards the source of our translation, especially in the context of other translations of secular material, and the fact that the greatest variation is found in the

\footnotetext{
${ }^{8}$ See also a current project on the language of Middle Welsh religious texts (Parina 2016).
} 
religious parts of the text, where the translator goes out of his way to pay homage to the central narrative of Christianity, Holdenried seems to be correct as far as our Middle Welsh translation is concerned - which is of course just one example of one translation, and therefore witness to one approach to a text with a particularly long history of transmission and reinterpretation.

Aberystwyth University

\section{References}

Baron, J. and Haffen, J., 1987, La Prophétie de la Sybille Tiburtine, Paris.

Haycock, M., 2005, “'Sy abl fodd, Sibli fain": Sibyl in Medieval Wales', in: J. F. Nagy and L. E. Jones, eds., Heroic Poets and Poetic Heroes in Celtic Tradition - a Festschrift for Patrick K. Ford, CSANA yearbook 34, Dublin, 115-30.

Holdenried, A., 2006, The Sybil and Her Scribes: Manuscripts and Interpretation of the Latin Sybilla Tiburtina c. 1050-1500, Bristol.

Luft, D., Thomas, P.W., Smith, D. M., 2013, Welsh Prose 1300-1425, Cardiff University (http://www.rhyddiaithganoloesol.caerdydd.ac.uk. [accessed 6.9.2016]).

Luft, D., 'Tracking ôl cyfieithu: Medieval Welsh translation in criticism and scholarship', Translation Studies, 9:2, 168-82.

Mac Cana, P., 1990, 'On the Uses of the Conjunctive Pronouns in Middle Welsh', in: Ball, Martin J., James Fife, Erich Poppe and Jenny Rowland, eds., Celtic Linguistics, Amsterdam, 411-34.

Lloyd-Morgan, C., 1978, A Study of Y Seint Greal in Rrelation to La Queste del Saint Graal and Perlesvaus, Unpublished DPhil, University of Oxford.

Parina, E., 2007, 'Coherence Markers: Conjunctive Personal Pronouns in Middle Welsh', Studia Celtica Fennica IV, 2007, 75-84.

Parina, E., 2016, The Language of Middle Welsh Religious Texts, poster presented at 9fed Gynhadledd Ieithyddiaeth Geltaidd, 1-2.09.2016, Caerdydd(http://www.unimarburg.de/fb10/iksl/sprachwissenschaft/forschung/p rojekte/projekt-parina/poster.pdf [accessed 6.2.2016]).

Sackur, E., Sibyllinische Texte und Forschungen. Pseudometodius, Adso und die Tiburtinische Sibille, Halle, 1898.

Van Seventer, N., 2011, Chwedleu y Seith Doethon Rufein, Unpublished RMA thesis, Utrecht. 